УДК 657.1

DOI: https://doi.org/10.32840/2522-4263/2019-5-63

Skrypnyk Nataliia

PhD in Economics, Associate Professor, Senior Lecturer at Accounting and Taxation Department Chernivtsi Institute of Trade and Economics of Kyiv National University of Trade and Economics

Skrypnyk Mykola

PhD in Economics, Senior Instructor at Accounting and Taxation Department Chernivtsi Institute of Trade and Economics of Kyiv National University of Trade and Economics

Скрипник Н.В. кандидат еконолічних наук, дочент, доцент викладач кафедри обліку і оподаткування Чернівецького торговельно-еконолічного інституту Київського національного торговельно-еконолічного університету

Скрипник М.C. кандидат еконолічних наук, старший викладач кафедри обліку $і$ оподаткування

Чернівецького торговельно-еконолічного інституту Київського національного торговельно-еконолічного університету

\title{
MANAGEMENT REPORTING IN THE MANUFACTURING BUSINESS AND ITS SPECIFICS
}

\section{ОСОБЛИВОСТІ ФОРМУВАННЯ УПРАВЛІНСЬКОЇ ЗВІТНОСТІ ВИРОБНИЧОГО ПІДПРИЕМСТВА}

\section{ANNOTATION}

The use of uniform accounting forms for all manufacturing business is problematic due to the diversity of the specifics of separate enterprises' activity and the peculiarities of a particular unit of the enterprise, its functions in the control system, the types of production processes, task orientation. Therefore, the preparation of managerial reports is not legally regulated and there is an internal matter of the particular manufacturing business. A managerial report makes it possible to predict further development: increase sales, reduce costs, and increase the profitability of individual units or businesses, increasing the value of the enterprise as a whole. Based on internal accounting, manufacturing business takes decisions at all levels. An important element in decision-making is the time from receiving the report to develop a solution and implement it in life. The availability of internal report forms, layout and presentation of relevant information has essential value. Proposed managerial reports' formats will allow evaluating the enterprise activity on a certain date. Thus, reporting includes data, which don't consider the time lag between the transaction and obtain information about it for adopting the necessary management decisions. Accordingly, there appears the necessity of using data of control performance indicators, which contain information about manufacturing business activity, which will allow tracking changes in it.

Key words: management accounting, management reporting, principles of reporting, management levels, centres of responsibility.

\section{АНОТАЦІЯ}

На сучасному кризовому етапі розвитку економіки держави одним з головних завдань управлінського обліку є задоволення інформаційних потреб менеджерів різних рівнів управління, важливими, також $€$ перелік, зміст та принципи розроблених форм управлінської (внутрішньої) звітності. Тому, при розробці методики складання та обробки управлінської звітності потрібен зважений підхід щодо термінів подачі управлінської звітності, кількісного та якісного представлення даних, їх формату. Застосування єдиних звітних форм для усіх виробничих підприємств є проблематичним у зв'язку з різноманітністю специфіки діяльності окремих підприємств, а також особливостями роботи конкретного підрозділу підприємства, його функціями в системі управління, видів виробничих процесів, цільової спрямованості. Отже, актуальним є питання фрормування ефективних фрорм управлінської звітності виробничих підприємств. Доведено, що управлінська звітність - це комплекс інформаційної підтримки процесу управління, система взаємопов'язаних оціночних показників, які характеризують умови та результати діяльності виробничого підприємства в цілому або складових його елементів, шляхом підготовки звітів у формі і терміни, які відповідають запитам різних груп користувачів. Управлінська звітність дає можливість прогнозувати подальший розвиток: збільшення обсягу реалізації, скорочення витрат, підвищення рентабельності окремих підрозділів або видів бізнесу, збільшення вартості підприємства в цілому. В результаті проведеного дослідження автором наведено систему формування управлінської звітності виробничого підприємства. Розроблений формат управлінської звітності дозволять дати оцінку діяльності підприємства на певну дату. Таким чином, у звітності наводяться дані, що не враховують часовий проміжок між здійсненням операції і отриманням інформації про неї для ухвалення необхідного управлінського рішення. Відповідно до цього виникає необхідність використання даних контрольних показників ефективності, які містять інформацію про діяльність швейного підприємства, що дозволить відстежувати зміни, які в ньому відбуваються. Запропоновано форми управлінської звітності за багатостадійною системою чотирирівневого управління виробничим підприємством: ділянка, цех, основне виробництво та підприємство в цілому, що дозволить оперативно та ефективно, тобто з мінімальними витратами, отримувати необхідну інформацію з потрібною деталізацією для прийнятті управлінських рішень на усіх рівнях управління виробничим підприємством.

Ключові слова: управлінський облік, управлінська звітність; принципи звітності; рівні управління; центри відповідальності. 


\section{АННОТАЦИЯ}

На современном кризисном этапе развития экономики государства одной из главных задач управленческого учета является удовлетворение информационных потребностей менеджеров различных уровней управления, важными, также есть перечень, содержание и принципы разработанных форм управленческой отчетности. Применение единых отчетных форм для всех производственных предприятий проблематично в связи с разнообразием специфики деятельности отдельных предприятий, а также особенностями работы конкретного подразделения предприятия, его функциями в системе управления, видов производственных процессов, целевой направленности. В результате проведенного исследования автором приведена система формирования управленческой отчетности производственного предприятия. Предложены фрормы управленческой отчетности по многостадийной системе четырехуровневого управления производственным предприятием участок, цех, основное производство и предприятие в целом, что позволит оперативно и эффективно, то есть с минимальными затратами, получать необходимую информацию с нужной детализацией для принятии управленческих решений на всех уровнях управления производственным предприятием

Ключевые слова: управленческий учет, управленческая отчетность, принципы отчетности, уровни управления, центры ответственности.

Formulation of the problem. One of the main tasks of management accounting is to meet the information needs of managers of different levels of management, also list, content, and principles of developed forms of management (internal) accounting are important. So, the development of methods of preparation and processing of managerial reports needs a balanced approach to the timing of the submission of managerial reports, quantitative and qualitative data presentation and their format.

The use of uniform accounting forms for all manufacturing business is problematic due to the diversity of the specifics of separate enterprises' activity, and the peculiarities of a particular unit of the enterprise, its functions in the control system, the types of production processes, task orientation. Therefore, the preparation of managerial reports is not legally regulated and there is an internal matter of the particular manufacturing business.

Analysis of publications. Questions about the nature of managerial reports are discussed in the works of many scientists and economists such as E.V. Akchurina, L.P. Solodko, A.V. Kazin [1, p. 35], P.J. Atamas [2, p. 112], S.V. Bulgakova [3, p. 109], D.M. Vasylkivskyi [4, p. 114], O.D. Hudzynskyj, H.H. Kirejtsev, T.M. Pakhomova [5, p. 92], Z. Hutsajliuk [6, p. 16], Ja.V. Sokolov [7, p. 12], H.B. Titarenko, M.D. Korinko $[9$, p. 67].

Summarizing the variety of perspectives, we propose to consider that the managerial reports is a complex of information support of management process, interconnected system of performance indicators that characterize the condition and performance of the manufacturing business as a whole or its constituent elements by preparing accounts in the form and terms that meet the needs of different user groups.

A managerial report makes it possible to predict further development: increase sales, reduce costs, and increase the profitability of individual units or businesses, increasing the value of the enterprise as a whole.

The purpose of the article is to identify and study forms, content, and principles of managerial reports of the manufacturing business.

Presentation of the main research material. Based on internal accounting, manufacturing business takes decisions at all levels. An important element in decision-making is the time from receiving the report to develop a solution and implement it in life. The availability of internal report forms, layout and presentation of relevant information has essential value.

So, first, let's consider the basic principles and requirements for the preparation of manufacturing business managerial reports. The effectiveness of the management reporting system can only be achieved by following certain principles (Fig. 1).

During the preparation, a management report should follow basic principles - efficiency, namely the costs of preparing managerial reports form cannot exceed the effect resulting from its use. There are a number of other principles, according to which internal reports are forming and providing.

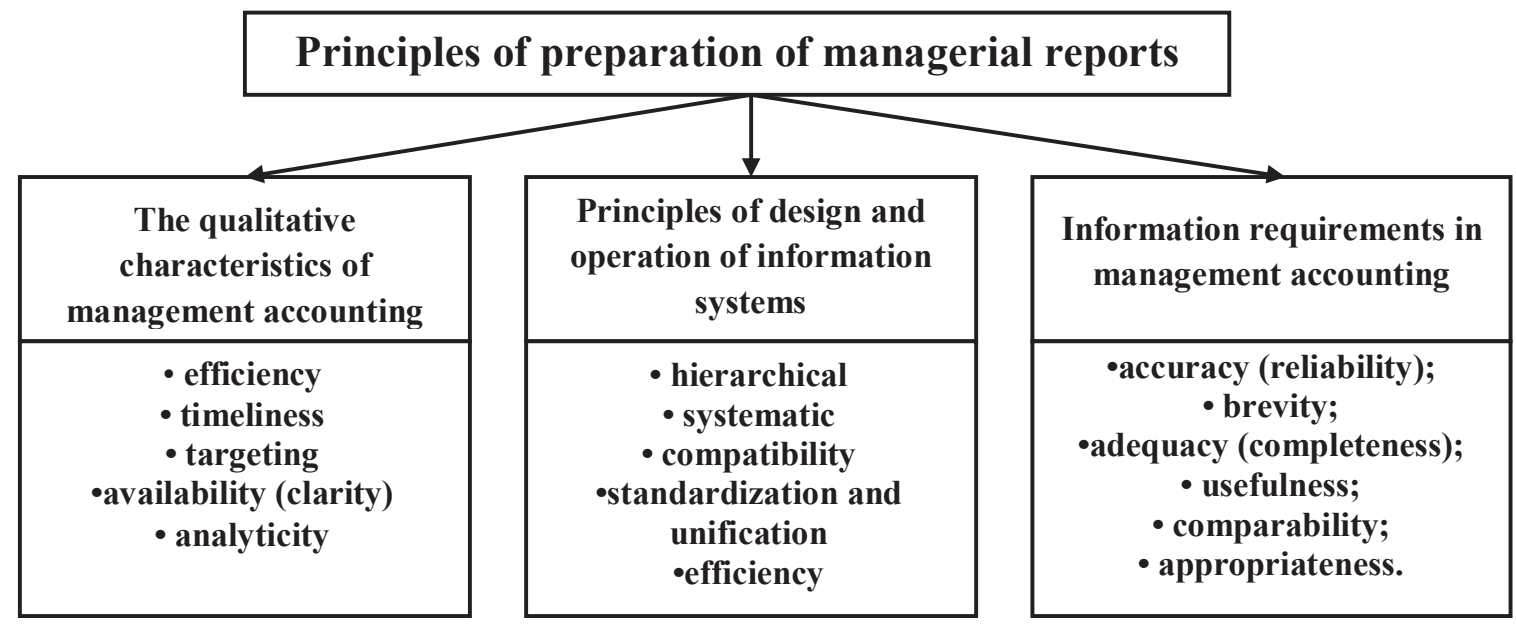

Fig. 1. Classification of principles of managerial reports 
The most important of these are: hierarchical accounting, namely the principle of multi-accounting by levels of management; targeting and specificity of the report; the report must contain current information useful for decision-making; the report should not be overloaded; information in the report should be systematic; comparable data; the report should be analytical and specific, namely, it must facilitate decision-making.

Management reporting system - one of the most difficult and important elements of management accounting, which allows management of the enterprise, on the one hand, to understand the limits of their capabilities to obtain the necessary information from the performers, and features information and technical services, on the other hand - get the data properly made, namely the form in which they are useful for decision-making. Besides, the system of managerial reports - a result of the activity of any management reporting system or, in other words, the product of its activity, that for which it is created in the enterprise [1, p. 36].

Further, we will consider the implementation phases and stages of accounting formation in more detail. An important prerequisite for the establishment of an effective system of internal enterprise accounting is a detailed study of the tasks, which managers decide at various levels of management, and the identification of an information needs that depend on the specific authority to adopt administrative decisions. To do this, they make information cards that contain the necessary information to be used for various structural units.

Besides, it is necessary to set the timing and frequency of submission of account forms and responsible persons. As for the list of main indicators, which are in managerial reports, special attention should be given to this issue.

According to the principle of "hierarchy" the detalization of indicators changes with increasing levels of leadership.

The essence of this approach is that the leaders of higher-level management do not need to check the detailed information in the accounts, compiled at a lower hierarchical level until there is any management problem. We propose the next structure of manufacturing business managerial reports:

- Level 1 - Accounting of section chief, crew, master;

- Level 2 - Accounting of department (division) chief;

- Level 3 - Accounting of production manager (by type);

- Level 4 - Accounting of enterprise.

The research shown that at the lower level of control in the responsibility centres the enterprise operational accounts are formed that contain detailed information for decision-making flows compiled daily, weekly and monthly, as the first-level administrative staff - foreman, master, etc. - need detailed information about costs: the time and place of occurrence, causes and cul- prits. At this level, there is direct consumption of resources and there are those able to secure their rational use according to established cost parameters. Required at this level amount of information about costs should be available every day.

This account form provides effective control over:

- compliance with the rules and regulations of various kinds of expenditure of resources;

- quality of decisions (based on the analysis of the effects generated by the decisions taken).

The leaders of the second level - heads of departments (units) - are also involved in operational management activities. Since all sorts of targets of production are forming in the context of workshops, size costs (estimates of production costs on the shop floor, the estimate of total production costs, planned payroll, etc.), maintained accounting records, consolidated accounting information about production costs on the shop floor. However, unlike the first-level managers, they do not need such detailed data, they are interested in general information displayed in the current account containing aggregated information for this level of management, which is formed on a monthly basis [8, p. 21].

Another possible variant of managerial reports will include forms that contain key performance indicators of specific responsibility centres' activity and belong to those controlled by the head of the centre. So, a sewing workshop is a form that contains the results of activity, namely the output of products.

Responsibility centres' management report is prepared for each period (redistribution) of the production process or month in duplicate by shop superintendent and must be submitted in a timely manner in accordance with the approved schedule of documents in the enterprise accounting. After checking by the manager, accountant, and head of the enterprise, the second copy returns to the head of the structural unit and serves as a cumulative cost accounting document, scope of work, manufacturing products from the beginning of the year to the accounting month, the period (processing, process). Another copy serves as a tool for theh reconciliation of accounting and control data in the consolidated management statement for structural units.

Managerial employees of the third level are production managers (by activity). It is necessary to have aggregate data grouped in the appropriate sections, describing the segment and results. The manager needs information, which helps make management decisions and he is not interested in detailed information. In the case of misunderstandings and difficulties, the manager can use the detailed information of the first and second levels of management. At this level of control, it is necessary to have information about what share of the profit the company received less due to current losses and accordingly, the amount of missed profit $[6, \mathrm{p} .16]$. 
Thus, managerial reports should contain only those parameters, which are controlled by a specific centre manager and the value which it can influence. On the one hand, the reports include information about deviations, which allows realizing the principle of disability management. According to this principle, the top-level manager can influence the activity of lower subordinated responsibility centres only when the lower level has a problem that manifests itself as a deviation from the set data.

Important principles of managerial reports form preparing during the implementation of accounting by responsibility centres is the principle of accounting by management levels. The fourth-level managerial employees are the management team of the manufacturing business. The highest-level managerial reports, presenting the results of the enterprise activity as a whole for the period, in turn, should have more details because it is the basis for various tasks (budget analysis, assessment of the feasibility of new products or borrowing to finance current activities).

The main goal of the highest-level managerial reports is to introduce the activity of the manufacturing business as the activity of a single entity, its financial position at the balance sheet date, and the financial results for the period. Functions of formation rely on the financial services of the enterprise (accounting), which must be specified in the order of accounting policies for the purposes of management accounting and workflow schedule.

The preparation of enterprise managerial reports is based on combining information, which is contained in the reports of lower levels, however, enterprise accounting should not include indicators describing internal operations, namely, relations between individual business units. So, the managerial report contains detailed information about the causes and perpetrators of deviations and about measures to eliminate these deviations.

Conclusions. Proposed by the author managerial reports' formats will allow evaluating the enterprise activity on a certain date. Thus, reporting includes data, which don't consider the time lag between the transaction and obtain information about it for making necessary management decisions. Accordingly, there appears the necessity of using data of control performance indicators, which contain information about manufacturing business activity, which will allow tracking its changes.

Thus, as a result of research on manufacturing business managerial reports formation system, we can make the following generalizations. Forms of managerial reports by a multistage system of manufacturing business four-level management are proposed: area, workshop, core production, and the enterprise as a whole, which will allow obtaining necessary information with the required detalization quickly and efficiently, namely, with minimal cost for decisions made at all manufacturing business management levels.

\section{REFERENCES:}

1. Akchurina, E.V., Solodko, L.P., Kazin, A.V. (2009). Upravlencheskij uchet [Management Accounting]. Progress, - Moscow, 480 p. (in Russ).

2. Atamas, P.J. (2006). Upravlinskyj oblik [Management Accounting]. Tsentr navchalnoi literatury, Kyiv, 440 p. (in Ukr.).

3. Bulgakova, S.V. (2006). Upravlencheskij uchet: problemy teorii [Managerial Accounting: problems of theory]. Voronezh, $160 \mathrm{p}$. (in Russ).

4. Vasylkivskyi, D.M. (2012). Analysis of the possibilities of realization mechanism of increasing the economic potential of the company. Visnyk Khmelnytskoho natsionalnoho universytetu [Herald of Khmelnytsky National University], vol. 3, pp. 113-115 (in Ukr.).

5. Hudzynskyj, O.D., Kirejtsev, H.H., Pakhomova, T.M. (2008). The theoretical aspects of accounting and analytical management mechanism. Oblik i finansy APK [Accounting and Finance AIC], vol. 3, pp. 89-93 (in Ukr.).

6. Hutsajliuk, Z. (2007). Some of the reform of the accounting system: concept and realization. Bukhhalterskyj oblik $i$ audit [Accounting and Auditing], vol. 10, pp. 11-17 (in Ukr.).

7. Sokolov, Ja.V. (2009). Buhgalterskij upravlencheskij uchet : ot istokov do nashih dnej [Management accounting: from the beginnings to the present day]. Moscow, 213 p. (in Russ).

8. Skrypnyk, N.V., Skrypnyk, M.E. (2015). The essence of strategic management reporting and approaches for its formation. Mizhnarodnyj naukovyj zhurnal «Naukovyj ohliad» [International scientific journal "Science Review"], vol. 5 (15), pp. 19-26 (in Ukr.).

9. Titarenko, H.B., Korinko, M.D. (2010). Methodological approaches for the construction of accounting and analytical systems using peer reviews. Oblik i finansy APK [Accounting and Finance AIC], vol. 4, pp. 66-69 (in Ukr.).

\section{БІБЛІОГРАФІЧНИЙ СПИСОК:}

1. Акчурина Е.В., Солодко Л.П., Казин А.В. Управленческий учет : учебный практикум. Москва : Прогресс, 2009. 480 с.

2. Атамас П.Й. Управлінський облік : навчальний посібник. Київ : Центр навчальної літератури, 2009. 440 с.

3. Булгакова С.В. Управленческий учет: проблемы теории : монография. Воронеж, 2006. 160 с.

4. Васильківський Д.М. Аналіз можливості реалізації механізму підвищення економічного потенціалу підприємства. Вісник Хмельницького національного університету. 2012. № 3. C.113-115.

5. Гудзинський О.Д., Кірейцев Г.Г., Пахомова Т.М. Теоретичні аспекти формування обліково-аналітичного механізму менеджменту. Облік і фонанси АПК. 2008. № 3. С. 89-93.

6. Гуцайлюк 3. Деякі питання реформування системи бухгалтерського обліку: концепція та реалізація. Бухгалтерський облік і аудит. 2007. № 10. С. 11-17.

7. Соколов Я.В. Бухгалтерский управленческий учет: от истоков до наших дней : монографиия. Москва, 2009. 213 с.

8. Скрипник Н.В., Скрипник М.Є. Сутність стратегічної управлінської звітності та підходи щодо її формування. Міжнародний науковий журнал «Науковий огляд». 2015. № 5. С. 19-26.

9. Тітаренко Г.Б., Корінько М.Д. Методичні підходи для побудови обліково-аналітичної системи з використанням експертних оцінок. Облік і фрінанси АПК. 2010. № 4. С. 66-69. 